\title{
GILBOAPHYTON ARGENTINUM SP. NOV.: A HERBACEOUS LYCOPOD FROM THE EARLY CARBONIFEROUS OF ARGENTINA
}

\author{
HUGO ALFREDO CARRIZO \\ Sección Paleobotánica, Fundación Miguel Lillo, Miguel Lillo 251, (4000) San Miguel de Tucumán, \\ Argentina.hugocarrizo5@hotmail.com \\ CARLOS LEOPOLDO AZCUY \\ CONICET, Departamento de Ciencias Geológicas, Universidad de Buenos Aires, Ciudad Universitaria, Pabellón 2, \\ (1428) Buenos Aires, Argentina.azcuy@ciudad.com.ar
}

\begin{abstract}
A new species of a herbaceous lycophyte with tripartite leaves is attributed to Gilboaphyton Arnold on the basis of the leaf morphology and the hexagonal shape of its leaf bases on the stem surface. The new species includes specimens previously classified as Archaeosigillaria conferta (Frenguelli) Menéndez, a primitive lycophyte which has been considered of biostratigraphic value in the Lower Carboniferous of Argentina. The excellent preservation of its delicate leaves adpressed to the stem has allowed to recognize its tripartite shape.. The fossil remains are from lower strata of the Jaramillo Formation, in the Tepuel - Genoa Basin in NW Patagonia, Argentina. Gilboaphyton argentinum Carrizo \& Azcuy sp. nov. is compared with the two species of Gilboaphyton Arnold, G. goldringiae Arnold from New York and G. griersonii Berry \& Edwards from Venezuela. Its age is discussed and it is concludes that the biocron of the genus Gilboaphyton has to be extended into the Early Carboniferous.
\end{abstract}

Key words: Lycophyte, Gilboaphyton, Early Carboniferous, Southwest Argentina.

RESUMO - Uma nova espécie de licófita herbácea é proposta com base na morfologia de suas folhas e no modelo hexagonal de suas bases folilares na superfície do talo. A nova espécie inclui espécimens anteriormente referidos a Archaeosigillaria conferta (Frenguelli) Menéndez, uma primitiva licófita, a qual é atribuído um importante valor estratigráfico em formações do Carbonífero Inferior da Argentina. A excelente preservação do material, com delicadas folhas adpresas sobre o talo permitiu reconhecer seu carácter tripartido. Os restos fósseis aqui descritos são provenientes dos estratos basais da Formação Jaramillo, bacia Tepuel-Genoa, na região noroeste da Patagônia. Gilboaphyton argentinum sp. nov. é comparada a outras espécies de Gilboaphyton Arnold, tais como G. goldringiae Arnold de New York e G. griersonii Berry \& Edwards da Venezuela. Sua idade é discutida e se conclui que o biocron do gênero Gilboaphyton deve ser extendido ao início do Carbonífero.

Palavras-chave: Licófita, Gilboaphyton, Carbonífero Inferior, Sudoeste da Argentina.

\section{INTRODUCTION}

Among the primitive lycophytes of Argentina, one species has been repeatedly cited in scientific literature: Archaeosigillaria conferta (Frenguelli) Menéndez (1965). This species has been considered, in the last decades, of important stratigraphic value in the Lower Carboniferous of Argentina. The study of new collections, have allowed the clarification of the status of some specimens of this taxon, mainly on the basis of the leaf morphology.

The identification of tripartite leaves in specimens previously attributed to Archaeosigillaria conferta, considered in the light of research carried out by Berry \& Edwards (1997) on samples from Venezuela and New York State, makes it necessary to establish Gilboaphyton argentinum Carrizo \& Azcuy sp. nov., for those specimens in which this type of foliar morphology is recognized.

\section{GEOLOGICAL SETTING}

The study area is located in the northern part of Sierra de Tepuel, at the Tepuel-Genoa Basin, Chubut province, Argentina (Figure 1). The specimens, which are here assigned to Gilboaphyton argentinum sp. nov., were collected in the basal section of the Jaramillo Formation, 800 m northwest of Puesto Pardo within Estancia La Mimosa (Figure 2). The Tepuel - Genoa Basin is located in southwest Argentina and is one of the Pacific Basins alongside the Andes in southernmost South America. It is a back-arc basin extended between $43^{\circ}-45^{\circ} \mathrm{S}$ latitude and $70^{\circ}-71^{\circ} \mathrm{W}$ longitude. Most of its sedimentary filling has been assigned to the Upper Paleozoic. The geology of the Sierra de Tepuel has been studied by several authors (Suero, 1948; Lesta \& Ferello, 1972; Andreis et al., 1985), who have proposed different interpretations of the stratigraphy of the Tepuel - Genoa Basin. 


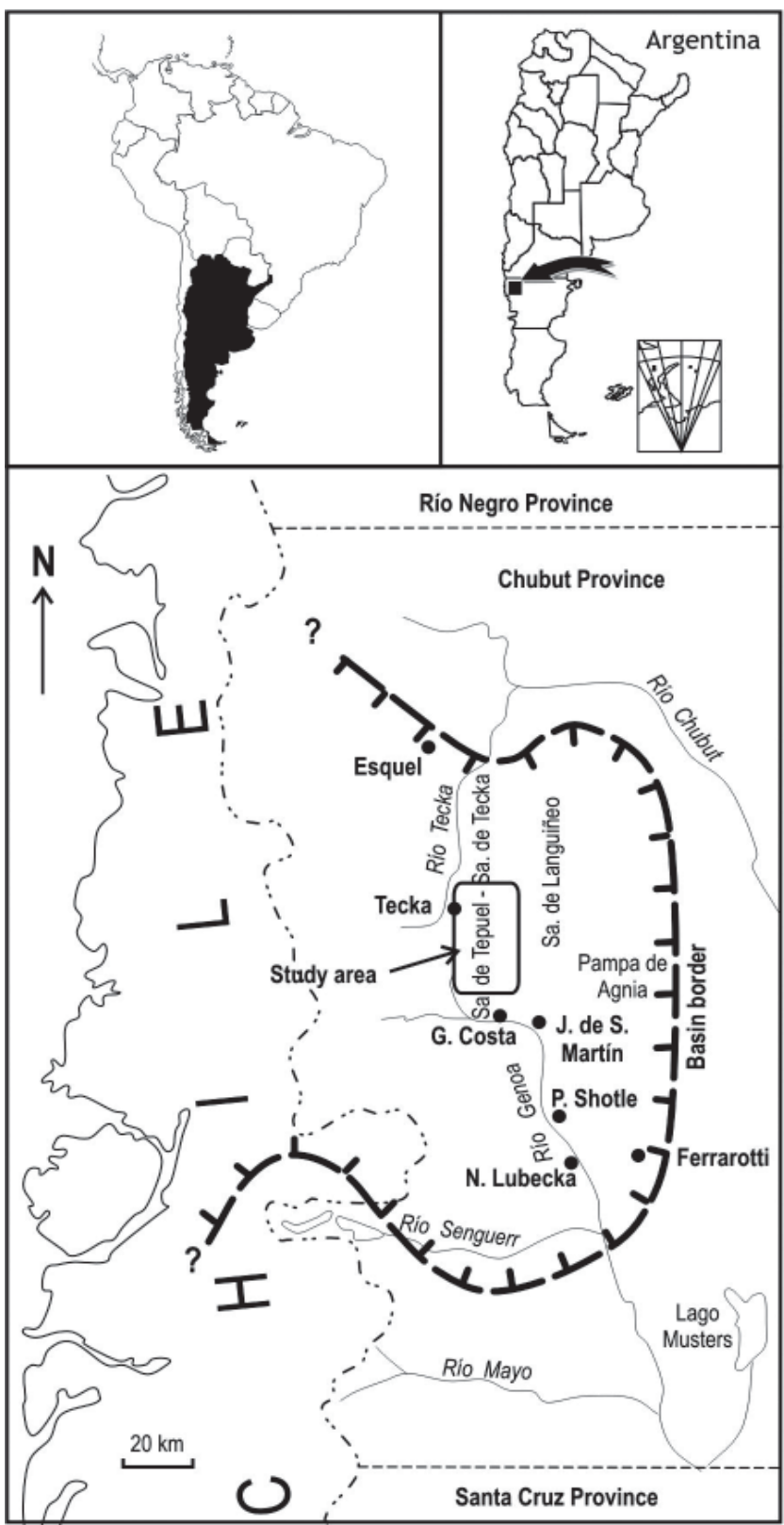

Figure 1. The Tepuel-Genoa Basin of Southwest Argentina, with location of the study area (adapted from González, 1984).

Suero (1948) includes the basin deposits in the "Tepuel System"; while Lesta \& Ferello (1972) define Tepuel Group to include the Pampa de Tepuel and Mojón de Hierro formations. Later, Andreis et al. (1985) include other units in the Tepuel Group, from oldest to youngest, the Jaramillo, Pampa de Tepuel, Mojón de Hierro and Río Genoa formations. The Tepuel Group is $5000 \mathrm{~m}$ thick and the strata are interpreted as marine and terrigenous deposits, with glacial deposits in the Pampa de Tepuel and Mojón de Hierro Formations (González Bonorino \& González Bonorino, 1988). The base of Tepuel Group does not crop out in the study area and is only observed in the Catreleo zone, on the western side of Sierra de Agnia (González Bonorino \& González Bonorino, 1988). The overlying sediments consist of Jurassic rocks in pseudoconformably relationship (Suero, 1948).
Page et al. (1984) provided details of the type section of the Jaramillo Formation (Figure 2A-B). These deposits are located on the western side of Sierra de Tepuel and have also been recognized in the Sierra de Tecka (González Bonorino et $a l .$, 1988). The Jaramillo Formation is dominated by sandstones with subordinate shales and conglomerates. These deposits are $1000 \mathrm{~m}$ thick and are the oldest of the Tepuel Group. Lacking a visible base, they are underlain paraconformibly by Pampa de Tepuel Formation (Figure 3). The sandstones form mostly compact tabular deposits, while dark grey shales are present in banks up to $4 \mathrm{~m}$ thick (Figure 2B).

The basal strata of the Jaramillo Formation were deposited in a marine environment along the shore. This is inferred from the presence of undeterminable marine invertebrate (González, pers. comm.). In this section, the sandstones facies is poorly developed. Dark shales of a very fine grain predominate, which favoured the excellent preservation of delicate leaves of lycophytes, such as those illustrated herein. In the upper section the sedimentation took also place in a marine environment along the shore with the presence of floated stems fragments (Andreis et al., 1987; González Bonorino et al., 1988).

\section{MATERIAL AND METHODS}

Studies carried out in different lithostratigraphic units of the Lower Carboniferous of Argentina have recovered abundant fossil lycophytes, both in variety of species and amount of specimens. The species here analyzed has shown two main types of fossilization in the sense of Schopf (1975). The most common to be found in the greater part of the material, corresponds to imprints and their counterparts, in some cases together with coalified remains, which show details of the surface features.

The other fossilization process includes positive and negative moulds as well as casts. Although there is no information on the anatomical structure of these axes, their external morphology is clearly discernible, including occasionally, slight impressions of epidermal tissue.

However, the preservation of leaf features varies according to the type of lithology and its texture, as well as with the mode of fossilization and location with respect to the stem. When the leaves have been preserved adpressed directly above the stem it is possible to recognize their laminar morphology, whereas in most cases in lateral view the foliar characteristics may become masked by compression and be mistaken for truncated spines of simple morphology.

All the studied material is housed in the Paleobotanical Collection of the Fundación Miguel Lillo, Tucumán Province, Argentina. All numbers are prefixed LIL Pb which identify the paleobotanical collection.

\section{HISTORICAL REVIEW}

The first studies and descriptions of Devonian lycophytes from New York State were carried out by Vanuxem (1842), who considered that his specimen could be closely related to 


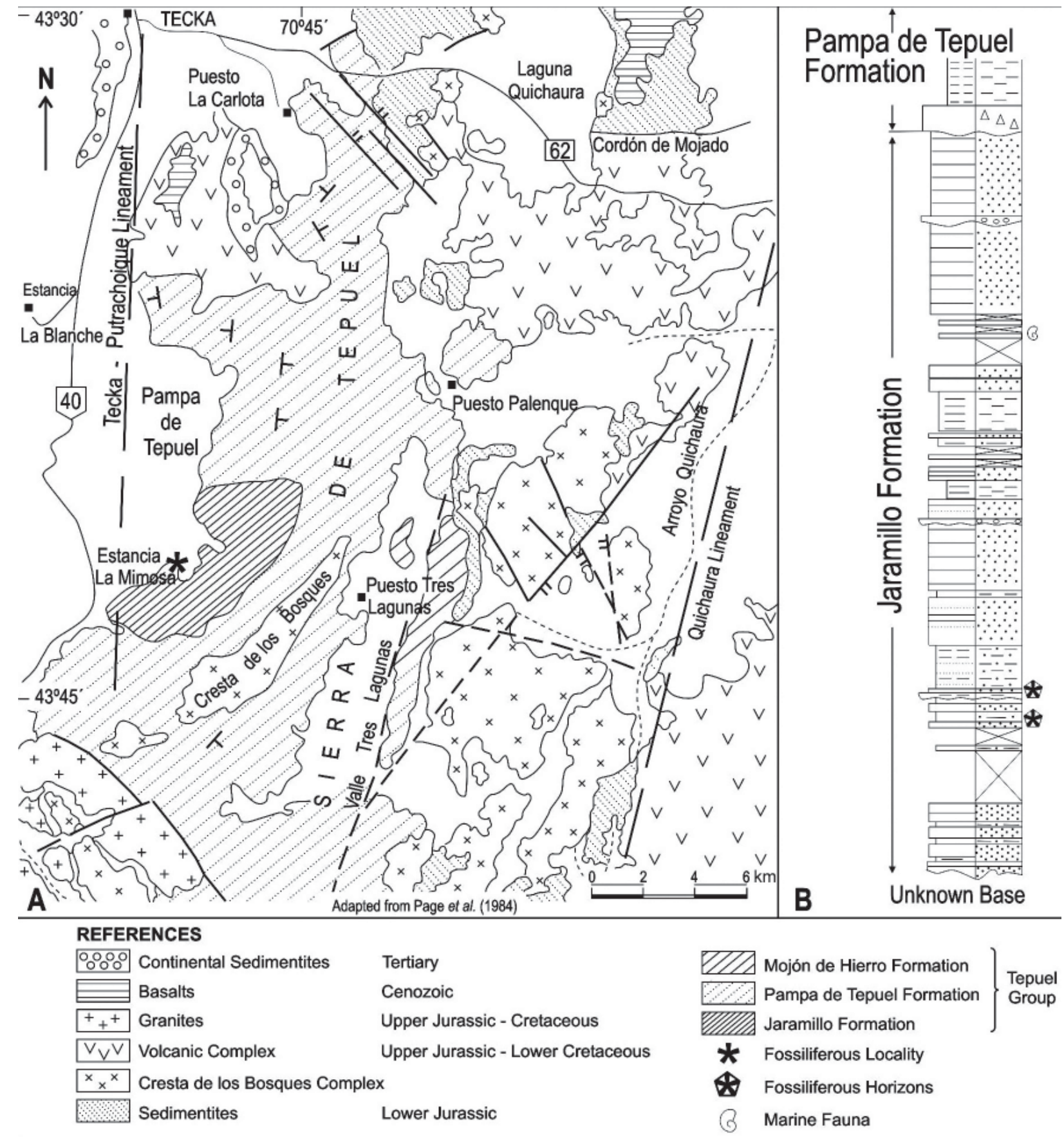

Figure 2. A, geological outline of the Sierra de Tepuel showing the distribution of the Jaramillo Formation (Lower Carboniferous) and the location of the fossiliferous locality; B, schematic columnar section of the Jaramillo Formation, in the northern region of the Sierra de Tepuel, showing fossiliferous horizons with Gilboaphyton argentinum sp. nov.

Lepidodendron Sternberg. Later, Göppert (1852) renamed it as Sigillaria vanuxemi, while Kidston (1885) refered the North American specimen, as well as some from the Early Carboniferous of England, to Lycopodites vanuxemi. Later, Kidston (1901) included the North American specimens together with those from the Early Carboniferous of Great Britain in the genus Archaeosigillaria, and designated $A$. vanuxemi as type species. Lacey (1962) and Grierson \& Banks (1963) carried out amendments to the generic diagnosis of Archaeosigillaria. Lacey incorporated cuticular details, while
Grierson \& Banks (1963) included aspects of leaf morphology. Later, while studying specimens from Gilboa in New York State, Arnold (1937) established the genus Gilboaphyton with G. goldringiae as type species. However, Kräusel \& Weyland (1949) considered Gilboaphyton goldringiae Arnold (1937) a synonym for Archaeosigillaria vanuxemi(Göppert) Kidston (1901), differentiating the material found in the North American Devonian from that having its source in the British Carboniferous. Likewise, they included some specimens of the Early Carboniferous of Great Britain 


\section{TEPUEL - GENOA BASIN}

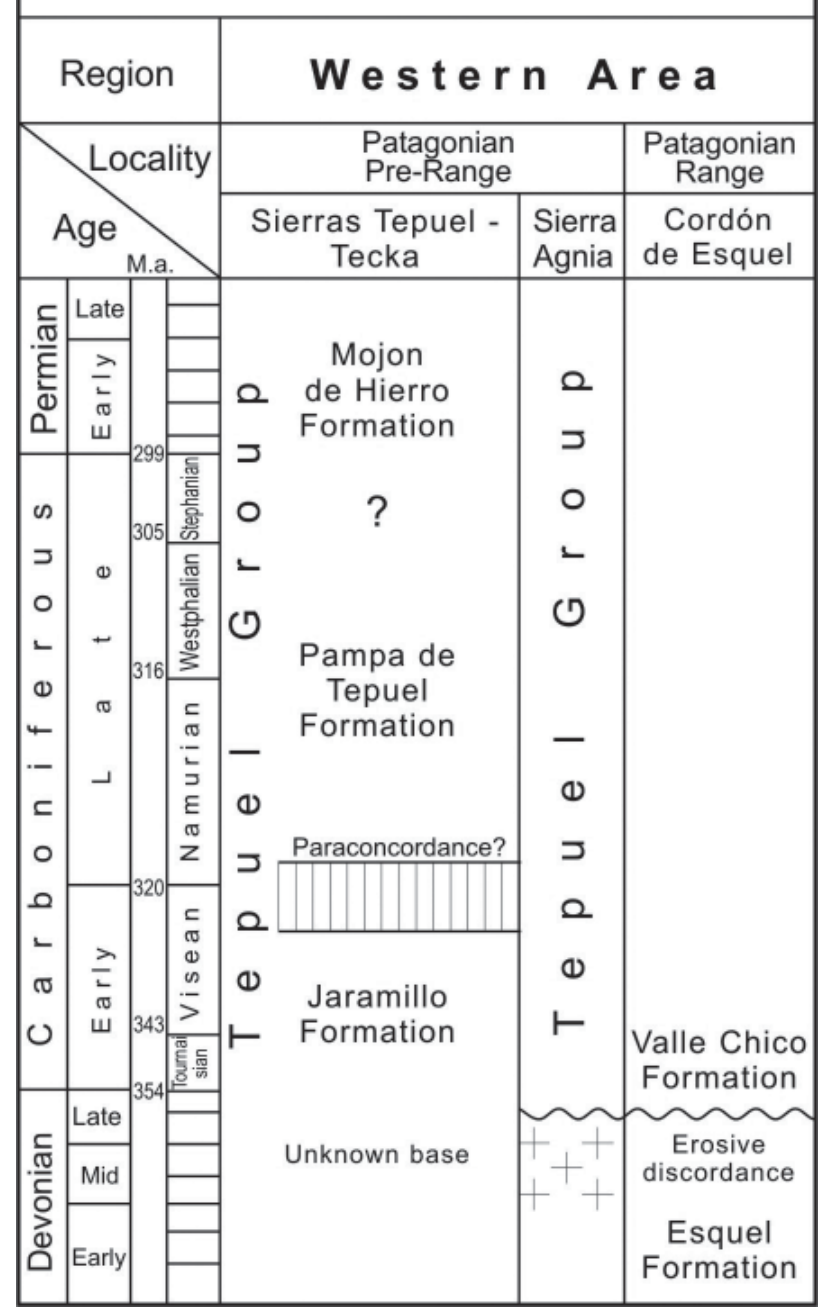

Figure 3. Upper Paleozoic stratigraphic units of the Sierras de Tepuel-Tecka, Agnia and Cordón de Esquel from Western Tepuel Genoa Basin. Carboniferous time scales after Menning et al. (2001).

assigned to Archaeosigillaria vanuxemi in the species Archaeosigillaria kidstonii Kräusel \& Weyland (1949). Fairon-Demaret \& Banks (1978) demonstrated the tripartite character of the leaf lamina in the Gilboa specimens, under the name $A$. vanuxemi.

The study of Berry \& Edwards (1997) using specimens from New York State, including the Archaeosigillaria type specimen, and others originated in the Venezuelan Devonian, allowed these authors to carry out a detailed revision of the genus Archaeosigillaria Kidston and to recognize its close relationship to the genus Gilboaphyton Arnold. Berry \& Edwards (1997) separate these genera because of the nonpreservation of leaves in the type specimen of Archaeosigillaria (A. vanuxemii) and the identification of tripartite leaves in the type species of Gilboaphyton ( $G$. goldringiae) as reported by Fairon-Demaret \& Banks (1978) under the name $A$. vanuxemii. They established a new species G. griersonii Berry \& Edwards (1997) to recognize the long, slender leaves of the Venezuelan species.

According to the concepts developed by Berry \& Edwards (1997), the uniting factor of Archaeosigillaria and Gilboaphyton is based on two facts: firstly the tripartite leaf lamina and secondly the hexagonal pattern of depressions surrounding the leaf bases on the surface of the stem.

In Argentina, an important number of specimens of herbaceous lycophytes have been recognized in different formations of the Lower Carboniferous, which have been identified as Archaeosigillaria conferta (Frenguelli) Menéndez (Menéndez, 1965; Petriella \& Arrondo, 1978; Gutiérrez \& Arrondo, 1994; Azcuy \& Carrizo, 1995). This collection of pieces attributed to A. conferta presents different types of preservation, which according to their frequency of occurrence are: cast, positive and negative moulds and impressions. In casts and positive moulds, protuberances corresponding to leaf bases are observed. Among other details, the negative moulds show the depressions caused by the leaves that have penetrated the sediment. In none of the reported records was possible to recognize leaves upon stems or to identify the morphology of the leaf lamina.

However, the very good preservation of the impressions collected in the Jaramillo Formation, Chubut province (Carrizo, 1998), has allowed for the first time the identification of the leaf lamina. By means of the interpretation of the total of recognized characteristics, it has been possible to identify the complete morphology of the leaves (Figures 4-5) and in that way to reconstruct the axes carrying tripartite vegetative leaves, in a helical pattern typical of this primitive lycophyte.

Based on the above stated, we agree with the criteria proposed by Berry \& Edwards (1997) and refer the lycophytes collected at the base of the Jaramillo Formation to Gilboaphyton argentinum sp. nov. On other hand, the examination the specimens referred to $A$. conferta (Frenguelli) Menéndez, in the light of the new generic amendment of Archaeosigillaria proposed by Berry \& Edwards (1997), will allow to name them accordingly.

\section{SYSTEMATIC RESULTS}

\author{
Class LYCOPHYTA \\ Order INCERTAE SEDIS \\ Family ARCHAEOSIGILLARIACEAE \\ Genus Gilboaphyton Arnold emend. Berry \& Edwards 1997
}

Gilboaphyton argentinum Carrizo \& Azcuy sp. nov.

(Figures 4, 5)

Holotype. LIL-Pb 7175(1)

Paratype. LIL-Pb 7175 (2)

Etymology. Regarding its occurrence in Argentina.

Repository. Paleobotanical Collection of the Fundación Miguel Lillo (LIL-Pb)

Type locality. Puesto Estancia La Mimosa, Tepuel Sierra, Chubut Province, Argentina.

Stratigraphic horizon. Jaramillo Formation, Lower section, Early Carboniferous. 

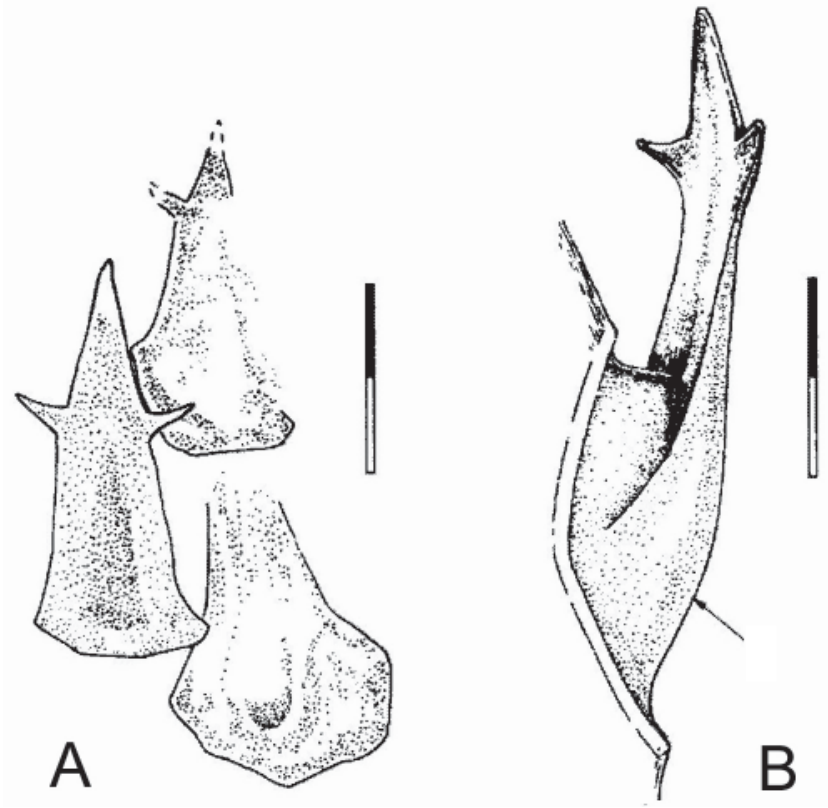

Figure 4. Gilboaphyton argentinum Carrizo \& Azcuy new species, LIL $\mathrm{Pb} 7175(2)$. A, drawing in camera lucida showing morphology of the leaf with the central and lateral segment in its distal portion; B, profile view showing the strong abaxial decurrence (arrow), the thickness of the base and the characteristic tripartite division in the distal portion. Scale bars $=2 \mathrm{~mm}$ for $\mathrm{A}$ and $1.5 \mathrm{~mm}$ for $\mathrm{B}$.

Additional specimens. LIL-Pb 7176, LIL-Pb7177, LIL-Pb7178, 7LIL-Pb179, LIL-Pb7182, LIL-Pb7183, LIL-Pb7187.

Diagnosis. Impressions of simple and ?ramified axes, herbaceous, covered by persistent laminar leaves, tripartite, attached to the stem at an acute angle and disposed in alternate verticils. Phyllotaxis sigillarioid. Conspicuous hexagonal leaf cushions, equidimensional (ca. $2 \mathrm{~mm}$ ), contiguous or slightly separated by narrow furrows, forming vertical lines. Leaves with asymmetric leaf bases of basal hexagonal-circular contour. Triangular lamina leaf is $4.5 \mathrm{~mm}$ long, with a characteristic tripartite division in its middle distal portion. Triangular middle segment is $1.5 \mathrm{~mm}$ long, distally curved upwards. Shorter acuminate lateral segments $(0.7 \mathrm{~mm})$ in an almost horizontal position. Leaf lamina and divisions with entire margins. From a lateral view the leaves resemble convex spines with respect to the axis, with a thick decurrent base. At the base of the leaves, carbonized approximately circular traces are interpreted as evidence of a leaf trace. Fructification unknown.

Type-specimen descriptions. The types LIL-Pb 7175(1/2) (Figures 4-5) correspond to an impression and a counterimpression, with traces of carbonization of a ?simple stem fragment preserving leaves above the stem and laterally. The scarce leaves seen in a lateral view (Figure 5B) resemble curved spines. However, the leaves above the stem are of a laminar appearance, tripartite and persistent, disposed in a spiral (Figure 5A). The basal portion of each leaf appears flattened, while the leaf lamina begins to emerge from both margins of the proximal parts of the leaf base. The lower part of the leaf lamina issues from the opposing lateral corners of the leaf base, where it presents its greater width (ca. $2 \mathrm{~mm}$ ) (Figure 5C-D). Then it curves upwards, where the adaxial side of the lamina forms a concave arch with respect to the stem. The lamina is $4.5 \mathrm{~mm}$ long, with a triangular shape and entire margins; $2.5 \mathrm{~mm}$ from the base two lateral, opposite acuminate segments $0.7 \mathrm{~mm}$ long are directed outwards. The $2 \mathrm{~mm}$ long acute medial segment curves upwards (Figure 5A, D). At the base of the leaves, carbonized approximately circular traces are frequently observed, which are interpreted as evidence of a leaf trace (Figure 5B-C).

Comparison and discussion. Abundant and well-preserved lycophytes of the Early Carboniferous of Argentina have been collected in formations belonging to the Tepuel - Genoa and Uspallata-Iglesia Basins of Patagonia and the Precordillera respectively (Menéndez, 1965; Menéndez, 1967; Azcuy \& Carrizo, 1995; Carrizo, 1998; Carrizo \& Azcuy, 2000). Some of the identified lycophytes in the Patagonian region have preserved their leaves on stems, one of the main diagnostic features which allow to assign them with systematic precision. The observation of these features has enabled us to state that the material coming from the Jaramillo Formation can be placed in a new species of Gilboaphyton Arnold emend. Berry \& Edwards. Gilboaphyton argentinum Carrizo \& Azcuy sp. nov. has been defined principally by its tripartite leaf lamina, with a large medial segment and two smaller and shorter opposite lateral segments and by their hexagonal leaf cushions. In axes of Gilboaphyton argentinum sp. nov. where only some complete leaves have been preserved, the morphology of their stems and leaf cushions is identical to that one observed in axes without leaves on stems previously assigned to "Archaeosigillaria" conferta (Frenguelli) Menéndez. These observations show that the axes here referred to Gilboaphyton argentinum sp. nov. as well as those identified as "Archaeosigillaria" conferta probably represent a single natural taxon corresponding to a lycophyte widely recognized in strata of the Early Carboniferous of Argentina (Menéndez, 1965; Azcuy \& Carrizo, 1995; Carrizo, 1998; Carrizo \& Azcuy, 2000).

Then, the use of the generic name Archaeosigillaria is restricted to designate provisionally those samples which in Argentina were assigned to the species "Archaeosigillaria" conferta. Such denomination shall be applied to those axes which clearly show the morphological characteristics of the leaf cushions and stem in which it is not possible to observe the morphology of the foliar lamina.

The two species of Gilboaphyton Arnold presently recognized, Gilboaphyton goldringiae Arnold (1937) and Gilboaphyton griersonii Berry \& Edwards (1997) are separated from Gilboaphyton argentinum Carrizo \& Azcuy sp. nov. by the characteristics that follow: Gilboaphyton argentinum sp. nov. differs from G. goldringiae in that the lateral segments occur in the middle-distal part of the lamina and the base of the leaf occupies all the width of the leaf base, while in G. goldringiae the lateral teeth occur at the widest part of the lamina, which has a narrow base. On the other hand, G. argentinum sp. nov. is separated from $G$. griersonii by the morphological characteristics of its stem in 

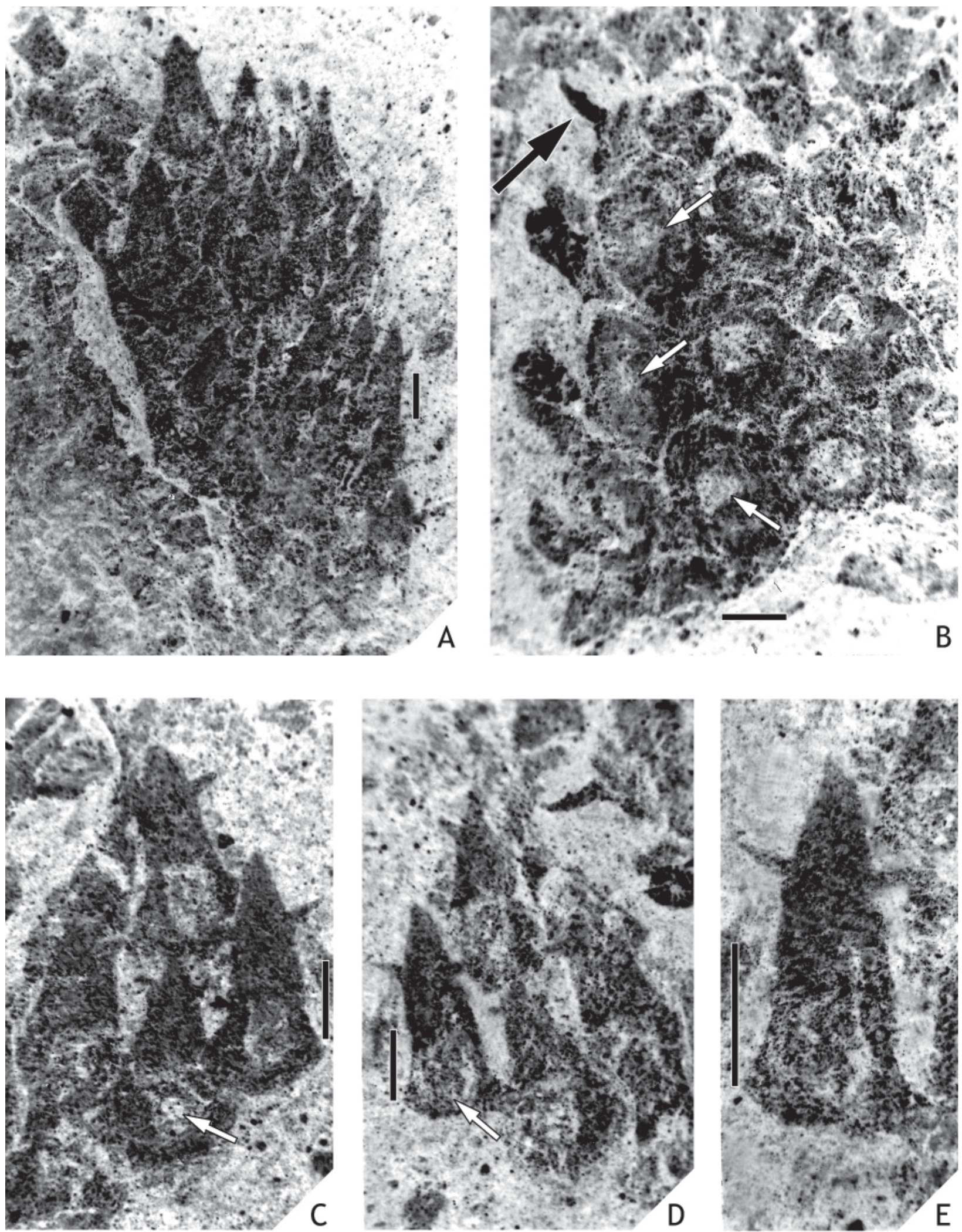

Figure 5. Gilboaphyton argentinum Carrizo \& Azcuy new species. A, LIL Pb 7175(1), impression of a simple axis with vegetative tripartite leaves upon stem, showing the morphology of the leaf lamina in an abaxial view; B, LIL Pb 7175(2), compressed leaf bases of hexagonal outline and leaf traces marks partially carbonized in the middle part of each leaf base (white arrow), in a lateral view, spine-shaped leaves (black arrow); C, LIL Pb 7175(1), abaxial view of complete tripartite leaves upon stem, emerging from hexagonal leaf bases, the basal portion appears flattened and the leaf lamina begins to emerge from the left and right margins of its base, at the base of the leaves leaf traces marks partially carbonized (white arrow); D, LIL Pb 7175(2), tripartite leaves upon stem, hexagonal leaf bases, leaf traces (white arrow), central segment of a greater size curved toward the stem and sharpened lateral segments; E, LIL Pb 7175(2), detail of tripartite leaf indicated by a white arrow in D. Photographs taken under water. Scale bars $=2 \mathrm{~mm}$. 
which hexagonal-circular, leaf bases of equal dimensions are observed, and by features of the leaf lamina whose central segment is shorter, wider and distally curved toward the stem with its lateral teeth almost horizontal, while in the Venezuelan species the leaf bases are widened forming broadly fusiform to hexagonal patterns, and there is a very slender central segment of the leaf lamina, slightly curved outwards and its opposite lateral teeth are twisted upwards.

\section{DISCUSSION OF AGE}

The age of Gilboaphyton argentinum sp. nov. is based on three groups of fossils: paleofloras, faunas and miospores. Paleofloras with "Archaeosigillaria" conferta (Frenguelli) Menéndez and/or Gilboaphyton argentinum are known in Argentina in four lithostratigraphic units: Jaramillo, Valle Chico, Malimán and Agua de Lucho (Menéndez, 1965; Azcuy \& Carrizo, 1995; Carrizo, 1998; Carrizo \& Azcuy, 2000). The first two correspond to Patagonia and the others to the Precordillera. The paleofloras recognized in these units are: Gilboaphyton argentinum sp. nov. and "Archaeosigillaria" conferta, in Jaramillo Formation; A. conferta and Eusphenopteris devonica (Frenguelli) Sessarego \& Césari in Valle Chico Formation; A. conferta, E. devonica, Frenguellia eximia Arrondo, Césari \& Gutiérrez and Diplothmema bodenbenderi (Kurtz) Césari in Malimán Formation; A. conferta, E. devonica and Pietzschia schulleri Gothan in Agua de Lucho Formation. These paleofloras are attributed in literature to the Early Carboniferous (Scalabrini Ortiz, 1972; Petriella \& Arrondo, 1978; Arrondo et al., 1991; Azcuy \& Carrizo, 1995; Carrizo, 1998; Carrizo \& Azcuy, 1998). On the other hand, in the Malimán and Agua de Lucho Formations they are associated with marine fauna corresponding to the Protocanites scalabriniiPaurorhyncha chavelensis Zone of Early Carboniferous age (González \& Bossi, 1987; González, 1993a; Sabattini et al., 2001) whereas in the Malimán Formation the levels with such megaflora overlay immediately or are associated with strata bearing a palynoflora composed of Verrucosisporites nitidus Playford, V. congestus Playford, Cordylosporites marciae Playford \& Satterthwait, Apiculiretusispora multiseta (Luber) Butterworth \& Spinner, A. semisenta (Playford) Massa, Coquel, Loboziak \& Taugourdeau-Lantz, Convolutispora insulosa Playford, Grandispora debilis Playford, Dibolisporites microspicatus Playford, Densosporites anulatus (Loose) Schopf, Wilson \& Bentall among other species of indubitable Early Carboniferous age (Césari \& Limarino, 1995; Rodríguez Amenábar et al., 2003). This data serves as a reference for correlations with other basins in the Argentinean west. Likewise, one must bear in mind that in Argentina, the Upper Paleozoic beds overlie the Devonian strata or ancient basement rocks in an angular unconformity. In the Precordillera, the strata of the Lower Carboniferous, which bear flora with $A$. conferta and marine fauna attributed to the Protocanites scalabrinii-Paurorhyncha chavelensis Zone (Sabattini et al., 2001) are separated from the Devonic strata by an unconformity which is attributed to the Chánica Phase (Turner \& Méndez, 1975). The Chánica Phase, that occurred during the end of the Devonian and beginning of Carboniferous times, was the most important tectonic episode which produced remarkable changes in the paleogeography of the Devonic and modelled the Neopaleozoic basins recognized in that region (Ramos, 1988; Azcuy \& Caminos, 1988; González, 1993b; Fernández Seveso \& Tankard, 1995; Azcuy et al., 1999). In Extraandean Patagonia, Upper Paleozoic sediments began to be deposited over basement of rock during the Early Carboniferous after tectonic event similar to the one that occurred in the Precordillera (González, 1984).

\section{FINAL CONSIDERATIONS}

The genus Gilboaphyton is recorded in strata of the Lower Carboniferous in Argentina for the first time.

Observation of leaves preserved upon the stem, allow verify that the axes of Gilboaphyton argentinum sp. nov. present a morphology of stems and leaf cushions identical to those axes without leaves upon stem previously assigned to "Archaeosigillaria" conferta (Frenguelli) Menéndez. The axes referred to Gilboaphyton argentinum sp. nov. and those identified as "A. conferta probably represent a natural taxon.

Gilboaphyton argentinum sp. nov., associated with "Archaeosigillaria" conferta, has been recognized in the Early Carboniferous of Argentina. Based on this, the biocron of the genus Gilboaphyton is extended to the Early Carboniferous.

\section{ACKNOWLEDGMENTS}

The authors gratefully acknowledge Christopher M. Berry (Cardiff University) for providing useful comments and a critical reading of the manuscript. We are indebted to the reviewers. Our thanks to Alberto Gutiérrez and Mario Corvalán-Singh (Fundación Miguel Lillo) for draftsmanship assistance. Financial support was obtained from the CONICET (PIP 2307/2000) and FONCyT (PICTR 313/2003). This is a contribution to the IGCP Project 471.

\section{REFERENCES}

Andreis, R.; González, C. \& Cortiñas, J. 1985. Estratigrafía de los Grupos Tepuel y Río Genoa (Neopaleozoico de Chubut). Revista Asociación Geológica Argentina, 40(3-4):284-289.

Andreis, R.; Archangelsky, S.; González, C.; López Gamundi, O. \& Sabattini, N. 1987. Cuenca Tepuel - Genoa. In: S. Archangelsky (ed.) El Sistema Carbonífero en la República Argentina. Academia Nacional de Ciencias Córdoba, p. 169-196.

Arnold, C.A. 1937. Observations on fossil plants from the Devonian of eastern North America. III. Gilboaphyton goldringiae gen. et sp. nov. from the Hamilton of eastern New York. Contribution Museum Paleontological University Michigan, 5:75-78.

Arrondo, O.G.; Césari, S.N. \& Gutiérrez, P.R. 1991. Frenguellia a new genus of lycopods from Early Carboniferous of Argentina. Review of Palaeobotany and Palynology, 70:187-197.

Azcuy, C.L. \& Caminos, R. 1988. Características paleogeográficas y diastróficas de algunas cuencas neopaleozoicas de América del Sur: una reseña. Boletín de la Sociedad Geológica del Perú, 78:203-224.

Azcuy, C.L. \& Carrizo, H.A. 1995. Archaeosigillaria conferta (Carbonífero Temprano) en el bolsón de Jagüé, La Rioja, Ar- 
gentina. Ameghiniana, 32(3):279-286.

Azcuy, C.L.; Carrizo, H.A. \& Caminos, R. 1999. Carbonífero y Pérmico de las Sierras Pampeanas, Famatina, Precordillera, Cordillera Frontal y Bloque de San Rafael. In: R. Caminos (ed.) Geología Argentina, Instituto de Geología y Recursos Minerales, p. 261-318.

Berry, C.M. \& Edwards, D. 1997. A new species of the lycopsid Gilboaphyton Arnold from the Devonian of Venezuela and New York State, with a revision of the closely related genus Archaeosigillaria Kidston. Review of Palaeobotany and Palynology, 96:47-70.

Carrizo, H.A. 1998. Estudio de floras eocarboniferas de Argentina y su comparación con las de otras regiones relacionadas. Facultad de Ciencias Naturales, Universidad Nacional de Salta, Tesis Doctoral, 304 p.

Carrizo, H.A. \& Azcuy, C.L. 1998. El perfil del cerro Mudadero y su flora fósil. Provincia de La Rioja, Argentina. Acta Geológica Lilloana, 18:81-99.

Carrizo, H.A. \& Azcuy, C.L. 2000. New paleobotanical evidence from the Valle Chico Formation (Lower Carboniferous), Chubut Province, Argentina. Revista de la Asociación Geológica Argentina, 55(3): 211-215.

Césari, S. \& Limarino, C. 1995. Primer registro palinológico de la Formación Malimán (Carbonífero Inferior), cuenca Río Blanco, Argentina. In: CONGRESO ARGENTINO DE PALEONTOLOGÍA Y BIOESTRATIGRAFÍA, 6, 1995. Actas, Trelew, p. 77-83.

Fairon-Demaret, M. \& Banks, H.P. 1978. Leaves of Archaeosigillaria vanuxemii a Devonian lycopod from New York. American Journal of Botany, 65:246-249.

Fernández-Seveso, F. \& Tankard, A.J. 1995. Tectonics and stratigraphy of the Late Paleozoic Paganzo Basin of Western Argentina and its regional implications. In: A.J. Tankard; R. Suárez Soruco \& H.J. Welsink (eds.) Petroleum Basin of South America, AAPG, p. 285-301.

González, C.R. 1984. Entidades estratigráficas neopaleozoicas de la Patagonia. In: ANNALS MEETING PROJET 211-IGCP, 1984. Abstracts, San Carlos de Bariloche, p. 22.

González, C.R. 1993a. Late Paleozoic Faunal succession in Argentina. In: CONGRÈS INTERNATIONAL DE STRATIGRAPHIE ET DE GÉOLOGIE DU CARBONIFÈRE ET PERMIEN, 12, 1991. Comptes Rendus, Buenos Aires, 1: 537-550.

González, C.R. 1993b. The earliest Carboniferous and the Devonian-Carboniferous boundary in Argentina. In: Newsletter on Carboniferous Stratigraphy, Krefeld, International Union for Geological Science - Subcommission on Correlation of Carboniferous Stratigraphy, p. 30-31 (Abstract Volume 11).

González, C.R. \& Bossi, G.E. 1987. Descubrimiento del Carbónico Inferior marino al oeste de Jagüel, La Rioja. In: CONGRESO LATINOAMERICANO DE PALEONTOLOGÍA, 4, 1987. Actas, Santa Cruz de la Sierra, 2:713-729.

González Bonorino, F. \& González Bonorino, G. 1988. La base del Grupo Tepuel en las cercanías de Esquel, Chubut. Revista de la Asociación Geológica Argentina, 43(4):518-528.

González Bonorino, G.; Rafine, G.; Vega, V. \& Guerín, D. 1988. Ambientes de plataforma nerítica dominada por tormentas en la sección glacigénica del Grupo Tepuel, Chubut. Revista de la Asociación Geológica Argentina, 43(2):239-252.Göppert, H.R. 1852. Fossile flora des Übergangsgebirges. Novorum Actorum Academiae Caesareae Leopoldino-Carolinae Germanicae Naturae Curiosorum, 22(suppl.):1-299.

Grierson, J.D. \& Banks, H.P. 1963. Lycopods of the Devonian of New York State. Palaeontographica Americana, 4(31):217-295.
Gutiérrez, P.R. \& Arrondo, O.G. 1994. Revisión de las licopsidas de la Argentina. 1. Archaeosigillaria Kidston y Frenguellia Arrondo, Césari y Gutiérrez. Ameghiniana, 31(4):381-393.

Kidston, R. 1885. On the occurrence of Lycopodytes (Sigillaria) vanuxemi Göppert in Britain, with remarks on its affinities. Journal of the Linnaean Society of Botany, 21:560-566.

Kidston, R. 1901. Carboniferous lycopods and sphenophylls. Transaction Natural History Society Glasgow, n.s., 6:25-140.

Kräusel, R. \& Weyland, H. 1949. Gilboaphyton und die Protolepidophytales. Pflanzenreste aus dem Devon XIV. Senckenbergiana, 30(1-3):129-152.

Lacey, W.S. 1962. Welsh Lower Carboniferous plants. I. The flora of the Lower Brown Limestone in the Vale of Clwyd, North Wales. Palaeontographica Abt. B, 111:126-160.

Lesta, P.J. \& Ferello, R. 1972. Región extraandina de Chubut y norte de Santa Cruz. In: A. Leanza (ed.) Geología Regional Argentina, Academia Nacional de Ciencias, p. 601- 653.

Menéndez, C.A. 1965. Archaeosigillaria conferta (Frenguelli) nov. comb. del Devónico de la quebrada de La Chavela, San Juan. Ameghiniana, 4(2):67-69.

Menéndez, C.A. 1967. Floras devónicas. In: Guía Paleontológica Argentina, Buenos Aires, Consejo Nacional de Investigaciones Científicas y Técnicas, p. 1-30 (Parte I, Sección 7)

Menning, M.; Weyer, D.; Drozdzewski, G. \& Wendt, I. 2001. More radiometric ages for the Carboniferous time scale. Newsletter on Carboniferous Stratigraphy, Subcommission on Correlation of Carboniferous Stratigraphy, p. 16-18 (Abstract Volume 19).

Page, R.F.N.; Limarino, C.O.; López Gamundi, O. \& Page, S. 1984. Estratigrafía del Grupo Tepuel en su perfil tipo y en la región El Molle, provincia del Chubut. In: CONGRESO GEOLÓGICO ARGENTINO, 9, 1984. Actas, Bariloche, 1:619-632.

Petriella, B. \& Arrondo, O.G. 1978. Presencia de Archaeosigillaria conferta (Frenguelli) Menéndez en el Carbónico Inferior de Argentina. Ameghiniana, 15(3-4):406-408.

Ramos, V. 1988. Late Proterozoic - Early Paleozoic of South America: a collisional history. Episodes, 11:168-174.

Rodríguez Amenábar, C.; di Pasquo, M. \& Carrizo, H.A. 2003. Datos palinológicos del límite Devónico/Carbonífero en la quebrada Cortaderas, provincia de San Juan, Argentina. In: SIMPOSIO ARGENTINO DE PALEOBOTÁNICA Y PALINOLOGÍA, 12, 2003. Resúmenes, Buenos Aires, MACN "Bernardino Rivadavia", p. 36-37.

Sabattini, N.; Azcuy, C.L. \& Carrizo, H.A. 2001. Invertebrados marinos de la Formación Malimán (Carbonífero Inferior), y su relación con las asociaciones paleoflorísticas. Revista de la Asociación Geológica Argentina, 56(1):111-120.

Scalabrini Ortiz, J. 1972. El Carbónico en el sector septentrional de la Precordillera sanjuanina. Revista de la Asociación Geológica Argentina, 27(4):351-377.

Schopf, J.M. 1975. Modes of fossil preservation. Review of Palaeobotany and Palynology, 20:27-53.

Suero, T. 1948. Descubrimiento del Paleozoico Superior en la zona extraandina del Chubut. Boletin de Informaciones Petroleras, 287:31-48.

Turner, J.C. \& Méndez, V. 1975. Geología del sector oriental de los departamentos de Santa Victoria e Iruya, provincia de Salta, República Argentina. Boletín de la Academia Nacional de Ciencias, 51(1-2): 11-24.

Vanuxem, L. 1842. Geology of New York. Part III. Comprising the Survey of the Third Geological District. New York, White Wisscher, $306 \mathrm{p}$.

Received in January, 2006; accepted in March, 2006. 